\title{
$\mathrm{P} / \mathrm{Rh}$ 比对 $\mathrm{PPh}_{3}-\mathrm{Rh} / \mathrm{SiO}_{2}$ 催化剂上丙烯氢甲酰化反应的影响
}

\author{
严 丽 ${ }^{1,2}$, 丁云杰 ${ }^{1,2}$, 刘 佳 ${ }^{1,2}$, 朱何俊 ${ }^{1,2}$, 林励吾 ${ }^{1,2}$ \\ ${ }^{1}$ 中国科学院大连化学物理研究所, 辽宁大连 116023 \\ 2 中国科学院大连化学物理研究所洁净能源国家实验室, 辽宁大连 116023
}

\begin{abstract}
摘要: 研究了 $\mathrm{P} / \mathrm{Rh}$ 比对 $\mathrm{PPh}_{3}-\mathrm{Rh} / \mathrm{SiO}_{2}$ 催化剂上丙烯氢甲酰化反应性能的影响. 结果表明, 当 $\mathrm{P} / \mathrm{Rh}$ 比为 15 时, 丙烯氢甲酰化反 应性能最好, 丙烯转化率为 $25.9 \%$, 产物丁醛正异比为 14 , 转换频率为 $241 \mathrm{~h}^{-1} . \mathrm{PPh}_{3}-\mathrm{Rh} / \mathrm{SiO}_{2}$ 催化剂的固体 ${ }^{31} \mathrm{P}$ 核磁共振结果表 明, 在合成气气氛下, 物理吸附的 $\mathrm{PPh}_{3}$ 能够溢流到 $\mathrm{Rh} / \mathrm{SiO}_{2}$ 表面形成化学吸附的 $\mathrm{PPh}_{3}$, 从而促进了具有氢甲酰化活性的铑膦络 合物的形成. Wilkinson 催化平衡理论也很好地解释了本实验结果.
\end{abstract}

关键词: 三苯基膦；铑；二氧化硅；膦铑比；丙烯；氢甲酰化；核磁共振

中图分类号: $\mathrm{O} 643$

文献标识码: A

\section{Influence of Phosphine Concentration on Propylene Hydroformylation over the $\mathrm{PPh}_{3}-\mathrm{Rh} / \mathrm{SiO}_{2}$ Catalyst}

\author{
YAN Li ${ }^{1,2}$, DING Yunjie ${ }^{1,2, *}$, LIU Jia ${ }^{1,2}$, ZHU Hejun ${ }^{1,2}$, LIN Liwu $^{1,2}$ \\ ${ }^{1}$ Dalian Institute of Chemical Physics, Chinese Academy of Sciences, Dalian 116023, Liaoning, China \\ ${ }^{2}$ Dalian National Laboratory for Clean Energy, Dalian Institute of Chemical Physics, \\ Chinese Academy of Sciences, Dalian 116023, Liaoning, China
}

\begin{abstract}
The effect of triphenyl phosphine concentration in the novel $\mathrm{PPh}_{3}-\mathrm{Rh} / \mathrm{SiO}_{2}$ catalyst for propylene hydroformylation was studied and found an optimum $\mathrm{P} / \mathrm{Rh}$ ratio of 15 , a butyraldehyde $n / i$ ratio of 14 , a butyraldehyde TOF of $241 \mathrm{~h}^{-1}$, and high catalytic stability for $\mathrm{PPh}_{3}-\mathrm{Rh} / \mathrm{SiO}_{2}$. Solid-state ${ }^{31} \mathrm{P}$ NMR shows that in an atmosphere of syngas the physically adsorbed $\mathrm{PPh}_{3}$ migrates onto the surface of $\mathrm{Rh} / \mathrm{SiO}_{2}$ where it chemically adsorbs and then promotes the in situ formation of carbonyl phosphine complexes.

Key words: triphenyl phosphine; rhodium; silica; phosphine/rhodium ratio; propylene; hydroformylation; nuclear magnetic resonance

与多相催化反应相比, 均相催化反应能够在较 温和的条件下具有较高的反应活性、选择性和可重 复性, 但产物分离过程繁琐, 严重阻碍了其在工业中 的应用. 而传统的多相催化反应具有产物易分离的 优点. 几十年来, 人们对均相催化剂固载化进行了 广泛研究, 所采用的载体包括有机多聚体、无机物和 杂化材料, 以及树枝状嵌合体 ${ }^{[1 \sim 7]}$. 但仍存在催化剂 活性组分的流失以及催化剂易失活等问题, 且活性 和选择性低, 至今仍没有固载化均相催化剂工业应 用的实例 ${ }^{[8]}$. 所以, 开发一种具有高活性、高选择性

而且活性组分不流失的多相催化体系仍面临巨大的 挑战.

近年来, 基于多年积累的多相催化方面的研究 经验, 本课题组成功开发了一种有机膦配体修饰的 $\mathrm{PPh}_{3}-\mathrm{Rh} / \mathrm{SiO}_{2}$ 催化剂, 它兼具均相催化剂反应活性 高、选择性高、反应条件温和以及多相催化剂产物 易分离的优点 ${ }^{[9,10]}$. 鉴于均相氢甲酰化反应中, $\mathrm{P} / \mathrm{Rh}$ 比对 $\mathrm{HRhCO}\left(\mathrm{PPh}_{3}\right)_{3}$ 催化剂性能影响很大 ${ }^{[11 ~ 13]}$, 本 文系统研究了 $\mathrm{P} / \mathrm{Rh}$ 比对 $\mathrm{PPh}_{3}-\mathrm{Rh} / \mathrm{SiO}_{2}$ 催化剂上丙 烯氢甲酰化反应性能的影响.
\end{abstract}

收稿日期: 2010-09-17. 接收日期: 2010-11-09

联系人: 丁云杰. Tel/Fax: (0411)84379143; E-mail: dyj@dicp.ac.cn

基金来源: 国家重点基础研究发展计划 (973 计划, 2009CB623503); 国家自然科学基金 (20903090).

本文的英文电子版由 Elsevier 出版社在 ScienceDirect 上出版(http://www.sciencedirect.com/science/journal/18722067). 
$\mathrm{PPh}_{3}-\mathrm{Rh} / \mathrm{SiO}_{2}$ 催化剂制备、评价过程以及表征 结果参考文献 [9]. ${ }^{31} \mathrm{P}$ 固体核磁实验在 VARIAN Infinityplus 型核磁共振波谱仪上进行. 振动频率 $161.8 \mathrm{MHz}$ ，脉宽 $0.7 \mu \mathrm{s}$, 弛豫延迟时间 $3 \mathrm{~s}$, 使用 Chemagnetics Wideline NMR 探头和 $2.5 \mathrm{~mm} \mathrm{ZrO}_{2}$ 转 子, 转动频率 $12.0 \mathrm{kHz}$, 采样次数 500 次.

图 1 为 $\mathrm{P} / \mathrm{Rh}$ 比对 $\mathrm{PPh}_{3}-\mathrm{Rh} / \mathrm{SiO}_{2}$ 催化剂上丙烯 氢甲酰化反应产物丁醛正异比的影响. 可以看出, 当 $\mathrm{P} / \mathrm{Rh}$ 比为 6 , 反应 $8 \mathrm{~h}$ 左右, 正异比达最大 (为 12.02), 继续延长反应时间, 正异比开始降低, 至 75 $\mathrm{h}$ 时降到 7.14. 还可以看出, 随着 $\mathrm{P} / \mathrm{Rh}$ 比的增加, 丁 醛正异比逐渐增加, 且随反应时间的延长而降低的 趋势变缓. 当 $\mathrm{P} / \mathrm{Rh}$ 比为 20 , 反应 $8 \mathrm{~h}$ 左右, 正异比 达最大 (16.54), 随着反应时间的延长, 正异比缓慢 降低, 至 $120 \mathrm{~h}$ 后仍可保持在 13.31 .

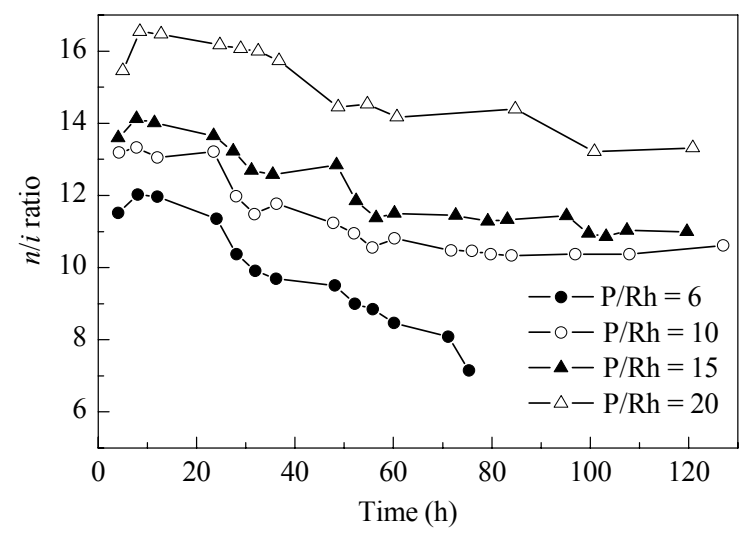

图 $1 \mathrm{P} / \mathrm{Rh}$ 比对 $\mathrm{PPh}_{3}-\mathrm{Rh} / \mathrm{SiO}_{2}$ 催化剂上丙烯氢甲酰化反应 产物丁醛正异比的影响

Fig. 1. Influence of $\mathrm{P} / \mathrm{Rh}$ ratio on the $n / i$ ratio of butyraldehyde over $\mathrm{PPh}_{3}-\mathrm{Rh} / \mathrm{SiO}_{2}$ catalyst. Reaction conditions: $T=393 \mathrm{~K}, p=1.0 \mathrm{MPa}$, $\mathrm{SV}=2000 \mathrm{~h}^{-1}$.

图 2 为 $\mathrm{P} / \mathrm{Rh}$ 比对 $\mathrm{PPh}_{3}-\mathrm{Rh} / \mathrm{SiO}_{2}$ 催化剂上丙烯 氢甲酰化反应产物丁醛转换频率 (TOF) 的影响. 由 图可见, 当 $\mathrm{P} / \mathrm{Rh}$ 比为 6 , 反应至 $28 \mathrm{~h}$ 时, 丁醛 $\mathrm{TOF}$ 可达到 $241 \mathrm{~h}^{-1}$, 然后迅速下降, 至 $75 \mathrm{~h}$ 时降到 99 $\mathrm{h}^{-1}$. 还可以看出, 丁醛 TOF 的最大值随 $\mathrm{P} / \mathrm{Rh}$ 比增 至 15 后变化不大, 但随着反应时间的延长, 其波动 明显变小. 当 $\mathrm{P} / \mathrm{Rh}$ 比为 20 时, 丁醛 $\mathrm{TOF}$ 值受反应 时间的影响变小, 但其最大值急剧降至 $64 \mathrm{~h}^{-1}$. 综合 考虑, 适宜 $\mathrm{P} / \mathrm{Rh}$ 比为 15 左右.

Evans 等 ${ }^{[14,15]}$ 对均相催化体系氢甲酰化反应机 理的研究表明, 在氢甲酰化反应条件下,

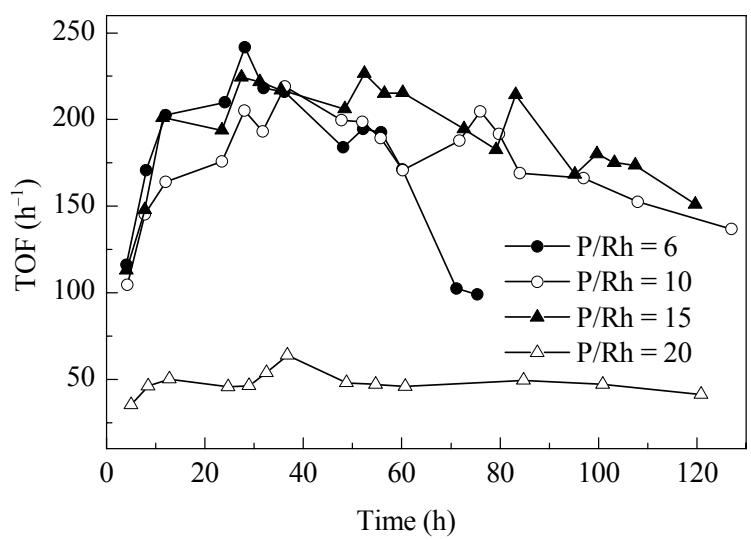

图 $2 \mathrm{P} / \mathrm{Rh}$ 比对 $\mathrm{PPh}_{3}-\mathrm{Rh} / \mathrm{SiO}_{2}$ 催化剂上丙烯氢甲酰化转换 频率的影响

Fig. 2. Influence of $\mathrm{P} / \mathrm{Rh}$ ratio on the TOF of butyraldehyde over $\mathrm{PPh}_{3}-\mathrm{Rh} / \mathrm{SiO}_{2}$ catalyst. Reaction conditions: $T=393 \mathrm{~K} ; p=1.0 \mathrm{MPa}$; $\mathrm{SV}=2000 \mathrm{~h}^{-1}$.

$\mathrm{HRh}(\mathrm{CO})_{m}\left(\mathrm{PPh}_{3}\right)_{n}$ 型络合物有多种存在形式, 每种络 合物的活性和选择性都不同, 如下面方程式中所示 的平衡:

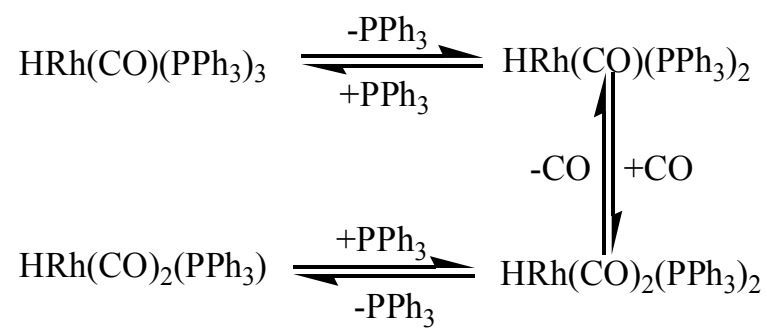

络合物的主要形式取决于 $\mathrm{CO}$ 和 $\mathrm{PPh}_{3}$ 的浓度. 我们前期工作证实 $\mathrm{PPh}_{3}-\mathrm{Rh} / \mathrm{SiO}_{2}$ 催化剂上原位生成 了 $\mathrm{HRh}(\mathrm{CO})\left(\mathrm{PPh}_{3}\right)_{3}$ 和 $\mathrm{HRh}(\mathrm{CO})_{2}\left(\mathrm{PPh}_{3}\right)_{2}$ 物种. 因此, $\mathrm{PPh}_{3}-\mathrm{Rh} / \mathrm{SiO}_{2}$ 催化剂上羰基铑膦配合物物种与均相 催化剂在溶液里的情况类似, 当 $\mathrm{P} / \mathrm{Rh}$ 比很低时, 羰 基铑膦配合物主要以 $\mathrm{HRh}(\mathrm{CO})_{2}\left(\mathrm{PPh}_{3}\right)$ 形式存在, 它 若再失去一个 $\mathrm{PPh}_{3}$ 就会导致催化剂失活. 如果提 高 $\mathrm{P} / \mathrm{Rh}$ 比, 平衡就会向左移动, 羰基铑膦配合物从 $\mathrm{HRh}(\mathrm{CO})_{2}\left(\mathrm{PPh}_{3}\right)$ 转换成以 $\mathrm{HRh}(\mathrm{CO})_{2}\left(\mathrm{PPh}_{3}\right)_{2}$ 为主, 而后者氢甲酰化活性较低, 选择性较高. 因此, 丁醛 正异比随着 $\mathrm{P} / \mathrm{Rh}$ 比的增加而不断提高, 但是丙烯转 化率和产物丁醛 TOF 值增至一个最大值后就变化 很小. 当 $\mathrm{P} / \mathrm{Rh}$ 比高于 15 , 铑膦配合物主要以 $\mathrm{HRh}(\mathrm{CO})\left(\mathrm{PPh}_{3}\right)_{3}$ 形式存在, 这个配合物最稳定, 活性 最差, 导致丙烯氢甲酰化活性很低. 膦配体浓度对 $\mathrm{PPh}_{3}-\mathrm{Rh} / \mathrm{SiO}_{2}$ 催化剂性能的影响与对 $\mathrm{HRh}(\mathrm{CO})\left(\mathrm{PPh}_{3}\right)_{3}$ 的影响类似, 这进一步证明 
$\mathrm{Rh} / \mathrm{SiO}_{2}$ 催化剂在氢甲酰化反应过程中原位生成了 类似的均相催化活性物种. 由于铑膦配合物化学平 衡比较复杂, 还很难依据现有的实验结果确定具体 的单一活性物种.

由于考察 $\mathrm{P} / \mathrm{Rh}$ 比对 $\mathrm{PPh}_{3}-\mathrm{Rh} / \mathrm{SiO}_{2}$ 催化剂性能 影响的过程中, 采用的是同一个催化剂前驱体 $\mathrm{Rh} / \mathrm{SiO}_{2}$, 发生变化的主要是 $\mathrm{PPh}_{3}$ 浓度, 因此本文采 用 ${ }^{31} \mathrm{P}$ MAS NMR 表征了合成气处理前后不同 $\mathrm{P} / \mathrm{Rh}$ 比的 $\mathrm{PPh}_{3}-\mathrm{Rh} / \mathrm{SiO}_{2}$ 催化剂, 结果示于图 3. 由图可 见, 位于 $\delta=-5.8$ 处的峰应归属于物理吸附在 $\mathrm{SiO}_{2}$ 上的 $\mathrm{PPh}_{3}$, 而 $\delta=+38.4$ 的峰应归属为化学吸附在 $\mathrm{SiO}_{2}$ 上的 $\mathrm{PPh}_{3}$ 或者是与 $\mathrm{Rh}$ 粒子化学配位的 $\mathrm{PPh}_{3}{ }^{[11 \sim 13]}$. 将 $\mathrm{PPh}_{3}-\mathrm{Rh} / \mathrm{SiO}_{2}$ 催化剂经一定量的合成 气处理后, 所有 $\mathrm{P} / \mathrm{Rh}$ 比的催化剂 ${ }^{31} \mathrm{P}$ MAS NMR 谱 中都仍然仅有两个吸收峰, 而且吸收峰位置也没有 变化.
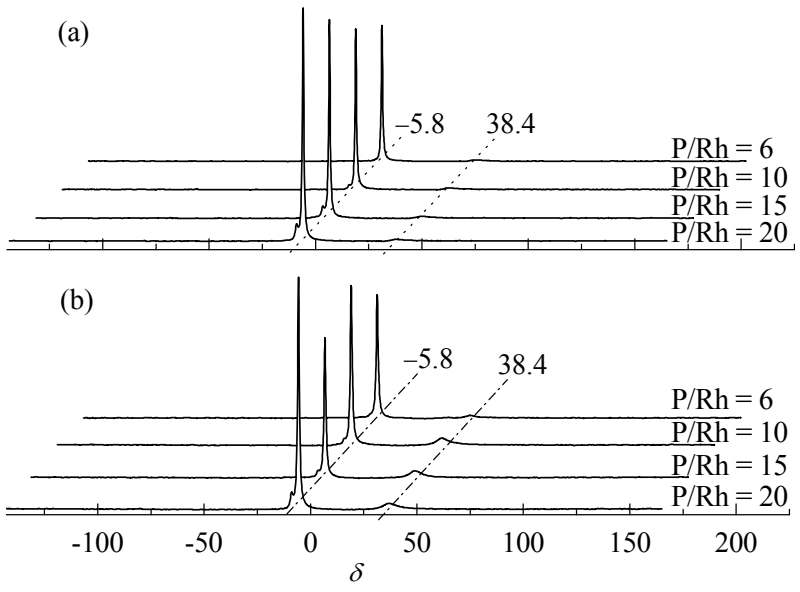

图 3 合成气处理前后不同 $\mathrm{P} / \mathrm{Rh}$ 比的 $\mathrm{PPh}_{3}-\mathrm{Rh} / \mathrm{SiO}_{2}$ 催化剂 的固体 ${ }^{31} \mathrm{P}$ MAS NMR 谱

Fig. 3. Solid-state ${ }^{31} \mathrm{P}$ MAS NMR spectra of $\mathrm{PPh}_{3}-\mathrm{Rh} / \mathrm{SiO}_{2}$ catalysts with different $\mathrm{P} / \mathrm{Rh}$ ratios before (a) and after (b) treated with syngas.

我们将合成气处理前后不同 $\mathrm{P} / \mathrm{Rh}$ 比的 $\mathrm{PPh}_{3}-\mathrm{Rh} / \mathrm{SiO}_{2}$ 催化剂的 ${ }^{31} \mathrm{P}$ MAS NMR 谱峰面积进 行积分, 并将各谱中的化学吸附和物理吸附的 $\mathrm{PPh}_{3}$ 的峰面积比示于图 4. 可以看出, 合成气处理前, $\mathrm{PPh}_{3}-\mathrm{Rh} / \mathrm{SiO}_{2}$ 催化剂随着 $\mathrm{P} / \mathrm{Rh}$ 比从 6 增加到 20 , 化 学吸附和物理吸附 $\mathrm{PPh}_{3}$ 的比值从 0.11 急剧下降到 0.01. 而经过合成气处理的各 $\mathrm{PPh}_{3}-\mathrm{Rh} / \mathrm{SiO}_{2}$ 催化剂 上该比值要高很多, 在 $\mathrm{P} / \mathrm{Rh}$ 比为 15 时, 达到最大, 为 0.33 , 然后随着 $\mathrm{P} / \mathrm{Rh}$ 比的增加而减小. 化学吸附 $\mathrm{PPh}_{3}$ 增加的原因可能是 $\mathrm{SiO}_{2}$ 载体表面的一部分物

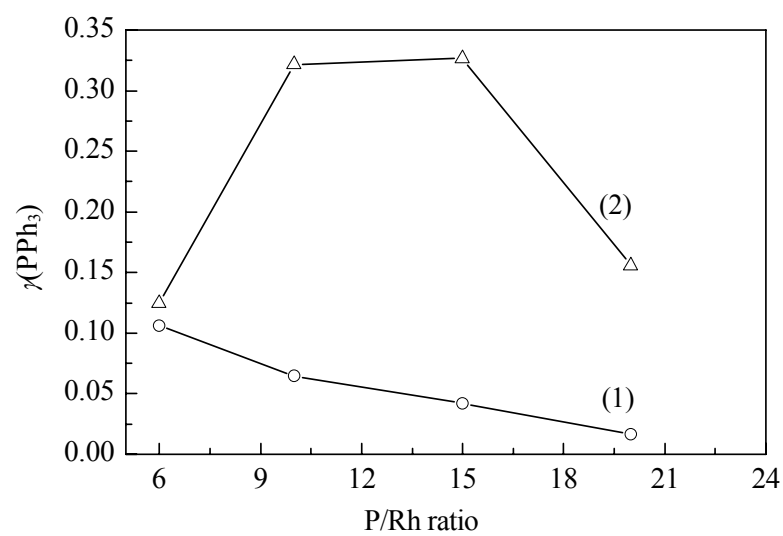

图 4 合成气处理前后不同 $\mathrm{P} / \mathrm{Rh}$ 比的 $\mathrm{PPh}_{3}-\mathrm{Rh} / \mathrm{SiO}_{2}$ 催化 剂的固体 ${ }^{31} \mathrm{P}$ MAS NMR 谱图中化学吸附与物理吸附的 $\mathbf{P P h}_{3}$ 的比值

Fig. 4. The ratio of chemically adsorbed $\mathrm{PPh}_{3}$ and physically adsorbed $\mathrm{PPh}_{3}\left(\gamma\left(\mathrm{PPh}_{3}\right)\right)$ in solid-state ${ }^{31} \mathrm{P}$ MAS NMR spectra of $\mathrm{PPh}_{3}-\mathrm{Rh} / \mathrm{SiO}_{2}$ catalysts with different $\mathrm{P} / \mathrm{Rh}$ ratio. (1) Before treatment with syngas; (2) After treatment with syngas.

理吸附的 $\mathrm{PPh}_{3}$ 发生了迁移.

比较图 1 和图 4 可以发现, 丁醛正异比随着 $\mathrm{P} / \mathrm{Rh}$ 比的增加而不断提高, 说明 $\mathrm{Rh}$ 表面化学吸附 的 $\mathrm{PPh}_{3}$ 越多, $\mathrm{Rh}$ 周围的配体数目越多, 空间位阻越 大, $\mathrm{Rh}$ 上电子云密度增加, 使反应物烯烃更易按反 马氏规则以 $-\mathrm{CH}_{2}-\mathrm{CH}_{2}-\mathrm{R}$ 形式插入 $\mathrm{Rh}-\mathrm{H}$ 键形成直 链产物。同时依据叔膦修饰的烯烃氢甲酰化反应机 理, 配体浓度的增加有利于反应按催化缔合机理进 行, 提高了反应对直链醛的选择性, 从而使产物正异 比升高. 当 $\mathrm{P} / \mathrm{Rh}=20$ 时, 丁醛 TOF 值下降, 这可能 是因为过量的配体将催化活性中心包埋, 造成活性 中心中毒.

综上所述, $\mathrm{P} / \mathrm{Rh}$ 比对 $\mathrm{PPh}_{3}-\mathrm{Rh} / \mathrm{SiO}_{2}$ 催化剂上丙 烯氢甲酰化反应影响很大, 当 $\mathrm{P} / \mathrm{Rh}$ 比为 15 时反应 活性最高. 而丁醛正异比随 $\mathrm{P} / \mathrm{Rh}$ 比增加而线性增 加, 即 $\mathrm{P} / \mathrm{Rh}$ 越高, 丁醛的正异比越高. 综合考虑, 我 们认为 $\mathrm{PPh}_{3}-\mathrm{Rh} / \mathrm{SiO}_{2}$ 催化剂在 $\mathrm{P} / \mathrm{Rh}$ 为 15 时达到最 优的催化性能. 固 体 ${ }^{31} \mathrm{P}$ MAS NMR 结果和 Wilkinson 平衡理论很好地解释了这一结果.

致谢 本论文中的固体 ${ }^{31} \mathrm{P}$ 核磁共振表征工作得到韩 秀文研究员的大力支持, 特此鸣谢.

\section{参考 文 献}

1 Mukhopadhyay K, Mandale A B, Chaudhari R V. Chem Mater, 2003, 15: 1766 
2 Chen R, Bronger R P J, Kamer P C J, van Leeuwen P W N M, Reek J N H. J Am Chem Soc, 2004, 126: 14557

3 Keim W, Driessen-Hölscher B. In: Ertl G, Knözinger H, Weitkamp J eds. Handbook of Heterogeneous Catalysis. Vol. 1. Weinheim: Wiley-VCH, 1997. 231

4 Arhanchet J P, Davis M E, Merola J S, Hanson B E. Nature, 1989, 339: 454

5 袁茂林, 付海燕, 李瑞祥, 陈华, 李贤均. 催化学报 (Yuan M L, Fu H Y, Li R X, Chen H, LI X J. Chin J Catal), 2010, 31: 1093

6 刘雯静, 袁茂林, 付海燕, 李瑞祥, 陈华. 催化学报 (Liu W J, Yuan M L, Fu H Y, Li R X, Chen H. Chin J Catal), 2009, 30: 577

7 Janssen M, Wilting J, Muller C, Vogt D. Angew Chem, Int Ed, 2010, 49: 7738

8 Cole-Hamilton D J. Science, 2003, 299: 1702

9 Yan L, Ding Y J, Zhu H J, Xiong J M, Wang T, Pan Z D, Lin L W. J Mol Catal A, 2005, 234: 1

10 Zhu H J, Ding Y J, Yan L, Lu Y, Li C, Bao X H, Lin L W. Chem Lett, 2004, 33: 630

11 Brown C K, Wilkinson G. J Chem Soc A, 1970: 2753

12 Hjortkjaer J. J Mol Catal, 1979, 5: 377

13 Pruett R L, Smith J A. J Org Chem, 1969, 34: 327

14 Evans D, Yagupsky G, Wilkinson G. J Chem Soc A, 1968: 2660

15 Evans D, Osborn J A, Wilkinson G. J Chem Soc A, 1968: 3133

\section{英 译 文 \\ English Text}

Homogeneous catalysts often exhibit higher selectivity, better reproducibility and reactivity under mild conditions in contrast to heterogeneous catalysts. However, the disadvantages of homogeneous catalysts include difficulties in the separation of the catalysts from the products after a reaction and this is not a problem with typical heterogeneous catalysts. The immobilization of homogeneous catalysts onto organic, inorganic, or hybrid supports has attracted widespread interest [1-7]. The main problems found in many systems are catalyst stability and the leaching of expensive metal ions from the catalysts to the product phase [8]. Recently, we developed a novel ligand modified heterogeneous catalyst $\left(\mathrm{PPh}_{3}-\mathrm{Rh} / \mathrm{SiO}_{2}\right)$ for the hydroformylation of olefins with excellent activity, selectivity, and stability $[9,10]$. No deactivation was observed over more than $1000 \mathrm{~h}$ on condition that $\mathrm{PPh}_{3}$ was supplemented at about 300-350 h in the $\mathrm{PPh}_{3}-\mathrm{Rh} / \mathrm{SiO}_{2}$ catalyst. The reason for the decrease in activity and selectivity of $\mathrm{PPh}_{3}-\mathrm{Rh} / \mathrm{SiO}_{2}$ from about 300 to $350 \mathrm{~h}$ is the leaching of $\mathrm{PPh}_{3}$.

The importance of having excess $\mathrm{PPh}_{3}$ present in solution for the regioselectivity of homogeneous hydroformylation has been well documented [11-13]. In general, excess ligand favors the formation of linear aldehydes at the expense of conversion. However, it should be noted that under certain experimental conditions both high rate and high regioselectivity may be encountered simultaneously. Therefore, we systematically investigated the influence of phosphine concentration on the activity, selectivity (especially $n / i$ ratio of butyraldehyde), and stability for propylene hydroformylation to determine the optimum $\mathrm{P} / \mathrm{Rh}$ ratio for the $\mathrm{PPh}_{3}-\mathrm{Rh} / \mathrm{SiO}_{2}$ catalyst in this work.

The synthesis and characterization of $\mathrm{PPh}_{3}-\mathrm{Rh} / \mathrm{SiO}_{2}$ as well as its hydroformylation reaction have been discussed in reference [9] in detail. We carried out solid-state ${ }^{31} \mathrm{P}$ MAS NMR experiments using a VARIAN Infinityplus spectrometer with a Chemagnetics Wideline NMR probe. Data were obtained by measuring the samples using a frequency of $161.8 \mathrm{MHz}$, a pulse width of $\pi / 4$, a delay of $3.0 \mathrm{~s}$, and 500 scans. Solid-state ${ }^{31} \mathrm{P}$ NMR chemical shifts were reported relative to $85 \% \mathrm{H}_{3} \mathrm{PO}_{4}$.

Influence of the $\mathrm{P} / \mathrm{Rh}$ ratio on the $n / i$ ratio of butyraldehyde in propylene hydroformylation is shown in Fig. 1. Generally, a short induction time of about $8 \mathrm{~h}$ was observed before the maximum $n / i$ ratio was obtained. The reason for the induction time is that the homogeneous active species grows gradually in situ on the surface of the heterogeneous $\mathrm{Rh} / \mathrm{SiO}_{2}$ catalyst [9]. When the $\mathrm{P} / \mathrm{Rh}$ ratio changes from 6 to 20 the $n / i$ ratio increases from 12.02 to 16.54 and the stability of the $n / i$ ratio increases.

Figure 2 shows the influence of the $\mathrm{P} / \mathrm{Rh}$ ratio on the turnover frequency (TOF) of the formation of butyraldehyde. We found that the TOF initially increases slowly as the $\mathrm{P} / \mathrm{Rh}$ ratio changes from 6 to 15 and then it decreases rapidly from 226 to $64 \cdot \mathrm{h}^{-1}$ when the $\mathrm{P} / \mathrm{Rh}$ ratio increases further. The stability of $\mathrm{PPh}_{3}-\mathrm{Rh} / \mathrm{SiO}_{2}$ improves from $60 \mathrm{~h}$ to $120 \mathrm{~h}$ when the $\mathrm{P} / \mathrm{Rh}$ ratio increases from 6 to 20 .

Evans et al. [14,15] reported that in a solution of $\mathrm{HRh}(\mathrm{CO})\left(\mathrm{PPh}_{3}\right)_{3}$, different rhodium carbonyl phosphine complexes are presented under hydroformylation conditions and each complex has its own specific activity and selectivity. The equilibrium can be represented as follows:

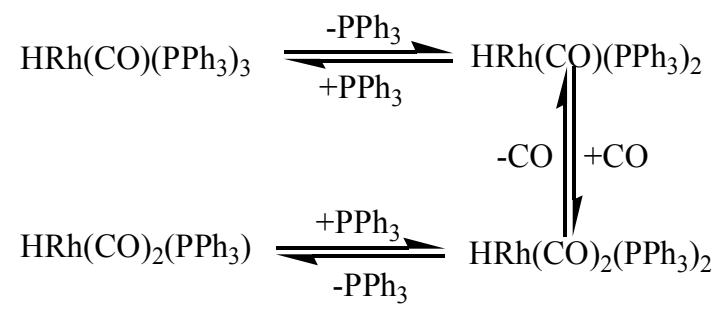

The complex that dominates is determined partly by the carbon monoxide concentration and by the phosphine concentration. Our previous work confirmed that the homogeneous active species of $\mathrm{HRh}(\mathrm{CO})\left(\mathrm{PPh}_{3}\right)_{3}$ and 
$\mathrm{HRh}(\mathrm{CO})_{2}\left(\mathrm{PPh}_{3}\right)_{2}$ can form in situ on the surface of the $\mathrm{PPh}_{3}-\mathrm{Rh} / \mathrm{SiO}_{2}$ catalyst [9]. Therefore, the rhodium carbonyl phosphine complexes on the $\mathrm{PPh}_{3}-\mathrm{Rh} / \mathrm{SiO}_{2}$ catalyst are comparable to those in a solution of $\mathrm{HRh}(\mathrm{CO})\left(\mathrm{PPh}_{3}\right)_{3}$. If the $\mathrm{P} / \mathrm{Rh}$ ratio is too low, the major rhodium carbonyl phosphine complex will exist as $\mathrm{HRh}(\mathrm{CO})_{2}\left(\mathrm{PPh}_{3}\right)$ and it may lose its single $\mathrm{PPh}_{3}$, which will lead to deactivation. By increasing the $\mathrm{P} / \mathrm{Rh}$ ratio, the equilibrium is shifted to the left. The dominant carbonyl phosphine complex shifts towards the less active but more selective $\mathrm{HRh}(\mathrm{CO})_{2}\left(\mathrm{PPh}_{3}\right)_{2}$ complex from the $\mathrm{HRh}(\mathrm{CO})_{2}\left(\mathrm{PPh}_{3}\right)$ complex. Therefore, the $n / i$ ratio increases with the $\mathrm{P} / \mathrm{Rh}$ ratio while the propylene conversion and the TOF reach their maximum values. However, if the $\mathrm{P} / \mathrm{Rh}$ ratio is higher than 15 , the main carbonyl phosphine complex is the $\mathrm{HRh}(\mathrm{CO})\left(\mathrm{PPh}_{3}\right)_{3}$ complex, which is the most stable but the least active complex and results in very low activity during propylene hydroformylation. The similarity in the effect of phosphine concentration on propylene hydroformylation between the $\mathrm{PPh}_{3}-\mathrm{Rh} / \mathrm{SiO}_{2}$ catalyst and $\mathrm{HRh}(\mathrm{CO})\left(\mathrm{PPh}_{3}\right)_{3}$ further confirms the in situ formation of the homogeneous active species on the surface of $\mathrm{Rh} / \mathrm{SiO}_{2}$ for the $\mathrm{PPh}_{3}-\mathrm{Rh} / \mathrm{SiO}_{2}$ catalyst during the hydroformylation of olefins. Because of the complexity of the equilibria involved, it is impossible to reach a firm conclusion solely on the experiments reported here.

For the preparation of the $\mathrm{PPh}_{3}-\mathrm{Rh} / \mathrm{SiO}_{2}$ catalysts with different $\mathrm{P} / \mathrm{Rh}$ ratios, the $\mathrm{Rh} / \mathrm{SiO}_{2}$ catalyst remains essentially the same with the only difference being the amount of $\mathrm{PPh}_{3}$. Therefore, solid-state ${ }^{31} \mathrm{P}$ MAS NMR is one of the best measurement tools to characterize the $\mathrm{PPh}_{3}-\mathrm{Rh} / \mathrm{SiO}_{2}$ catalysts with different $\mathrm{P} / \mathrm{Rh}$ ratios and the results are shown in Fig. 3 for the catalysts that were not treated and those that were treated with syngas, respectively. All the spectra in Fig. 3 imply that there are only two kinds of $\mathrm{PPh}_{3}$ in the $\mathrm{PPh}_{3}-\mathrm{Rh} / \mathrm{SiO}_{2}$ catalysts with different $\mathrm{P} / \mathrm{Rh}$ ratios: one is physically adsorbed $\mathrm{PPh}_{3}$ at $\delta=-5.8$ and the other is chemically adsorbed $\mathrm{PPh}_{3}$ at $\delta=+38.4$.

However, the ratio of chemically adsorbed $\mathrm{PPh}_{3}$ and physically adsorbed $\mathrm{PPh}_{3}$ for each spectrum are very different and this is shown in Fig. 4. For the $\mathrm{PPh}_{3}-\mathrm{Rh} / \mathrm{SiO}_{2}$ that was not treated, the ratio decreases from 0.11 to 0.01 and the $\mathrm{P} / \mathrm{Rh}$ ratio increases from 6 to 20 . After treatment with syngas, the ratio becomes larger and reaches the highest value 0.33 at a $\mathrm{P} / \mathrm{Rh}$ ratio of 15 . The increased chemically adsorbed $\mathrm{PPh}_{3}$ may migrate from the physically adsorbed $\mathrm{PPh}_{3}$ on the surface of the $\mathrm{SiO}_{2}$ supports.

The increased $n / i$ ratio that results from an increase in the $\mathrm{P} / \mathrm{Rh}$ ratio can also be explained by a comparison of the results shown in Figs. 1 and 4. These figures show that when more chemisorbed $\mathrm{PPh}_{3}$ is present on the $\mathrm{Rh}$ surface more steric hindrance will result and propylene will more likely insert into $\mathrm{Rh}-\mathrm{H}$ in the form of $-\mathrm{CH}_{2}-\mathrm{CH}_{2}-\mathrm{CH}_{3}$ to produce linear butyraldehyde. The decline in the TOF of butyraldehyde that was observed upon the further addition of $\mathrm{PPh}_{3}$ $(\mathrm{P} / \mathrm{Rh}=20)$ is considered to be the result of the active species being embedded by an excess of $\mathrm{PPh}_{3}$.

In summary, the use of excess $\mathrm{PPh}_{3}(\mathrm{P} / \mathrm{Rh}=15)$ in the $\mathrm{PPh}_{3}-\mathrm{Rh} / \mathrm{SiO}_{2}$ catalyst ensures high activity, selectivity, and stability for the hydroformylation of propylene on a fixed-bed reactor. When the $\mathrm{P} / \mathrm{Rh}$ ratio of the $\mathrm{PPh}_{3}-\mathrm{Rh} / \mathrm{SiO}_{2}$ catalyst changes from 6 to 20 , the $n / i$ ratio of butyraldehyde increases as well. However, the TOF of butyraldehyde reaches its maximum at a $\mathrm{P} / \mathrm{Rh}$ ratio of 15 . Subsequently, the best $\mathrm{P} / \mathrm{Rh}$ ratio for the $\mathrm{PPh}_{3}-\mathrm{Rh} / \mathrm{SiO}_{2}$ catalyst is 15 .

\section{Acknowledgments}

We thank Ms. HAN Xiuwen for obtaining the solid-state ${ }^{31} \mathrm{P}$ NMR spectra.

Full-text paper available online at ScienceDirect http://www.sciencedirect.com/science/journal/18722067 